\title{
ERROR ANALYSIS ON PRONOUN MADE BY THE ELEVENTH GRADE STUDENTS OF SMA KATOLIK CINTA KASIH TEBING TINGGI IN ACADEMIC YEAR OF 2020/2021
}

\author{
Aswani Jelita Sianturi, Novalina Sembiring, Fiber Yun A Ginting \\ Catholic University of Saint Thomas \\ Email :novalina_sembiring@ust.ac.id
}

\begin{abstract}
The Research was aimed to analyze the error on pronoun made by the eleventh grade students of SMA Katolik Cinta Kasih Tebing Tinggi in Academic Year of 2020/2021. The subject of this research consists of 30 students in XI-MIPA-1. The objectives of the study were (1) To find out the types of error made by students in using pronoun. (2) To find out what causes the students made such error in using pronoun. This research used qualitative approach with descriptive research. The errors were collected, identified, and classified based on the Surface Structure Taxonomy by Dulay. It was specified by four types of errors namely omission, addition, misordering, and misformation.

The result showed (1) The most common errors made by the students were misformation $(52,0 \%)$ or 88 errors. The second was error in addition with the frequency $(35,5 \%)$ or 60 errors. The third error was omission $(11,2 \%)$ or 19 errors. The lowest frequency of error was misordering $(1,1 \%)$ or 2 errors. (2) The students made such errors in using pronouns because of their less motivation of learning, lack of knowledge about grammar and English language, and minimal use of media by the teacher during teaching learning process. The teacher should create an interesting teaching, so it that can increase the students' interest in learning English.
\end{abstract}

Keywords: error analysis, pronoun, surface strategy taxonomy, descriptive qualitative research

\section{INTRODUCTION}

English is a important language. As a important and international language, people use English to communicate each other. However, many people use English as they like, without following the rules of using English. It happened with most students, they only use English when they are learning it in the class. Outside the class, very little student practice their English. As the result they make mistakes repeatedly when they use English.

Brown (2007:258) states that a error is a noticeable deviation from the adult grammar of a native speaker, reflecting the interlanguage competence of the learner. In order to analyze learner's errors, it is also needed to make a distinction between mistake and errors, technically to very different phenomena. A mistake refers to a performance error that is either a random guess or a slip, in that it is a failure to utilize a known system correctly.

English grammar are classified into eight parts of speech, i.e. verb, adverb, noun, pronoun, adjective, preposition, conjunction, and interjection. Each part of the speech explains not what the word is, but how the word is used. Kumar (2019:11) states that pronoun as one of grammar aspects is a word which replaces a noun. It is also a basic knowledge of English that should be mastered. 
Furthermore, students should understand about position and function of using pronouns within a sentence. The use of pronouns is important in writing. It will be complicated if student uses inappropriate pronouns in writing. Pronouns are divided into some types. Based on their types, it has different function and position. Therefore, pronouns should be taught in beginner level.

There are many types of pronoun in English which have different position and function. In English language, here are the types and the examples of pronoun; (a) subject: I, you, (b) object: me, them, (c) possessive adjective: my, their, (d) possessive pronoun: mine, yours, (e) reflexive pronoun: myself, yourself.

Based on the writer's experience during teaching practice program at SMA Katolik Cinta Kasih Tebing Tinggi, there are many errors made by the eleventh grade students of SMA Katolik Cinta Kasih Tebing Tinggi in using pronouns. Some of them are as follows:

1. Pulpen ini milik saya $\longrightarrow$ The pen is $\mathbf{I}$

(correct : this pen is mine)

In the first example, students made the error about changing the possessive pronoun become subject. The possessive pronoun must be "mine" because "I" is not possessive pronoun, but subject.

2. Ibu melihat saya di kamar $\longrightarrow$ Mother saw I in the bedroom (correct : Mother saw me in the bedroom)

In the second example, students made the error about changing the object become subject. The object must be "me" because "I" is not object, but subject.

Any errors produced can be caused by students' lack of English language, less vocabulary, lack of knowledge about grammar is so poor, and also because of their mother tongue which always influences them when using foreign language. The teacher should be aware of those errors and do something to avoid them by doing some correction. These fact encourages the writer to make the analysis of error made by the students and what cause them make such error.

\section{REVIEW OF LITERATURE \\ Definition of Error and Mistake}

Brown (2007:258) states that an error is a noticeable deviation from the adult grammar of a native speaker, reflects the competence of the learner. Error and mistake have identical meaning in teaching and learning process. In order to make a proper perspective between error and mistake, it is crucial to make a distinction between them. Mistake is related to performance of the learner that might occur in the speech and writing. Brown (2007: 257) states that a mistake refers to performance error that is either random guess or a "slip", in that it is a failure to utilize a known system correctly.

James (in Brown, 2007:258) states that a mistake can be self-corrected if the deviation is pointed out to the speaker, while error cannot be self-corrected. It can be concluded that errors happen because the learners have less understanding and knowledge in target language. While, mistakes are caused by temporary lapses of memory, confusion, and carelessness in expressing targets either in spoken or written form. So, from several statements above, error and mistake are not the same.

\section{The Classification of Errors}


James (2001:106) states that error classification based on surface Strategy Taxonomy. These errors consist four types: they are omission, addition, misformation and misordering.

\section{Omission}

Omission is characterized by the absence of an item that must appear in a well-formed utterance. Although any morpheme or word in a sentence is a potential candidate for omission, some types of morphemes are omitted more than others.

For example:

Error : I not angry with you.

Correct : I was not angry with you.

The bold italic word is omitted in which it should appear in well-formed utterance. It is the verb "am" or "was" that should have come after the subject. Dullay et.al (1982:155) state that omissions are found in greater abundance and across a greater variety of morphemes during the early stages of second language acquisition. As the examples above, language learners omit grammatical morphemes much more frequently than content words.

2. Addition

Addition errors are the opposite of omissions. This error is characterized by the presence of an item which must not appear in a well-formed utterance. It usually occurs in the later stage of second language acquisition when the learner has already acquired some target language rules. There are three types of addition; they are double marking, regularization, and simple addition. These are the explanations:

a. Double Marking

Double marking happens when two items rather than one are marked for the same feature.

For example: (In Past Tense)

Error : Angel did not went there yesterday.

Correct : Angel did not go there yesterday.

\section{b. Regularization}

A rule typically applies to a class of linguistic items, such as the class of nouns. In addition, Errors in which a marker that is typically added to a linguistic item is erroneously added to exceptional items of the given class that do not take a marker are called regularization errors. The example of this error can be seen in the term of regular, an irregular forms and construction in a language. The learner often applies the rules to produce the regular one to those that are irregular.

For example:

Error : Laura camed to her mother house 2 months ago.

Correct : Laura came to her mother`s house 2 months ago.

There is regularization of regular past, the verb come does not become camed, because come is an irregular verb .

c. Simple Addition

Simple addition is a term to express an error in which an addition is not a double marking nor regularization.

For example:

Error : I can played the game.

Correct: I can play the game.

There is simple addition in the sentence, the verb used must be verbs I after a modal.

3. Misformation

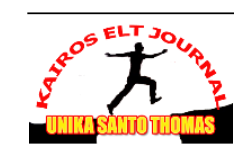


Misformation errors are characterized by the use of the wrong form of the morpheme or structure. According to Dullay et.al (1982:158), there are three types of misformations errors, they are:

a. Regularization Errors

Errors that belong to this category are those in which a regular marker is used in place of an irregular one, as in runned for run, hisself for himself or goed for go/goes.

For example:

Error : He rided his motorcycle.

Correct : He rode his motorcycle.

There is wrong change of verb ride, it should be rode.

b. Archi forms

Archi forms are the errors in which the learners select the member of class form to represent others in that class of certain function.

For example:

Error : This pencils are mine.

Correct : These pencils are mine.

The word this is not appropriate for plural, the appropriate one is these.

c. Alternating Form

Alternating forms are caused by the use of archi-forms that often gives way to the apparently fairly free alternation of various members of class with each other. For example:

Error : I written a letter yesterday.

Correct : I wrote a letter yesterday.

The form of the verb written is wrong, the correct one is wrote, because the example is past tense.

4. Misordering

These errors are characterized by the incorrect placement of morpheme or group of morphemes in an utterance.

For example:

Error : I did not know why was she sad.

Correct : I did not know why she was sad.

The placement to be "was" is wrong.

\section{The Sources of Errors}

Brown (2007:263) states that there are four sources of errors. They are interlingual transfer, intralingual transfer, the context of learning, communication strategies.

\section{Interlingual Transfer}

Interlingual transfer is a significant source of error for all learners. The beginning stages of learning a second language are especially vulnerable to interlingual transfer forms the native language, or interference. In these early stages, before the system of the second language is familiar, the native language is the only previous linguistic system upon which the learner can draw. We have all heard English learners say "sheep" for "ship", or "the book of Jack" instead of "Jack's book". Interlingual errors occur because of the interference of the learners' mother tongue into the target language.

\section{Intralingual Transfer}

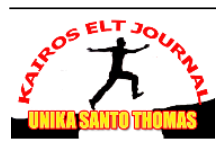


Intralingual transfer is major factor in second language learning. This error occurs when learners undergo progress in the second and their previous experience and their existing sub summers begin to include structures within the target language itself. Intralingual error happens in the target language itself.

\section{Context of Learning}

Context refers to the classroom with its teacher and its materials in the case of school learning or the social situation in the case of untutored second language learning. In a classroom context the teacher or the text book can lead the learner to make faulty hypothesis about the language. Students often make errors because of misleading explanation from the teacher, faulty presentation of a structure or word in a textbook.

For example: my mother is come here.

\section{Communication Strategies}

Communication strategies are defined and related to learning styles. Learners obviously use production strategies in order to enhance getting their messages across, but at times these techniques can themselves become a source of error.

\section{Causes of Errors}

Norrish (1983:21) states that there are some factors that causes of errors in a sentence such as :

\section{Carelessness}

Carelessness is the error caused by less inspiration of the students while they learn the second language or the uninteresting material that makes students less enthusiastic in learning the language.

2. First Language

First Language Interference is caused by the mother tongue that gets involved while the students are using the foreign language.

3. Translation

Translation is because of students blindly translating a sentence, phrase or an idiomatic expression from their first language into the language they are learning.

\section{Error Analysis}

Brown (2007:259) states that the fact learners do make errors, and that these errors can be observed, analyzed, and classified to reveal something of the system operating within the learner, led to a surge of study of learners' errors called error analysis. Error analysis became distinguished from contrastive analysis by its examination of errors attributable to all possible sources, not just those resulting from negative transfer of the native language.

\section{Procedures of Error Analysis}

Brown (2007:260) states that procedures of error analysis have two types namely:

1. Identifying Errors

The first step in the process of analysis is the identification and description of errors. The identification of errors involves a comparison between what the learner has produced and what a native speaker counterpart would produce in the 
same context. If the native language of the learner knows, the model indicates using translation as a possible indicator or native language interference as the source of errors.

\section{Describing Errors}

The describing of the error involves specifying how the form by the learner different from target language. For purpose of analysis, errors are usually classified according to language level (whatever errors are phonological, morphological and syntactic). General linguistic category, (e.g. auxiliary system, passive sentence, negative constructions), or more specific linguistic elements (e.g. articles, prepositions, verb form).

\section{Pronoun}

Kumar (2019:11) states that Pronoun is a word used to replaces of a noun. A pronoun is a word that can stand alone, it can stand in place of a noun, noun group or name. It usually needs to have a clear and consistent reference, referring to something that has been identified or named in the text. Payne (2011:75) explains that pronouns are anaphoric words which mean that they are tools that speakers use to refer or to mention participants and props on the discourse stage. The use of pronoun can be affected by the grammatical rule of the target language and the first language, since both languages might have different by using types and pronoun. Murphy (1998:124) states that there are some kinds of pronouns as follows:

\section{Personal Pronouns}

Personal pronouns can be divided into two categories:

1. Subject Pronouns

First person

Second person

Third person

\section{Examples :}

1. First person (singular)

2. Second person (plural)

3. Third person (singular)

Singular
I
You

He, She, It
Plural
We
You
They

$\Rightarrow$ I am a student

$\Rightarrow$ You are the winner

$\Rightarrow$ She is my mother

\section{Object Pronouns}

First person

Second person

Third person

\section{Examples :}

1. First person (plural)

2. Second person (singular)

3. Third person (plural)

$$
\begin{array}{cc}
\text { Singular } & \text { Plural } \\
\text { me } & \text { us } \\
\text { you } & \text { you } \\
\text { him, her, it } & \text { them }
\end{array}
$$

Plural

\section{Reflective pronouns}

Reflective pronouns are combination of -self with personal pronouns or with impersonal pronouns. The action of the verb is pointed back to the subject of the sentence.

Singular : myself, yourself, himself, herself, itself 
Plural

: ourselves, yourselves, themselves

Examples:

Singular

Plural

$$
\begin{aligned}
& =>\text { I am going to buy myself new bag } \\
& =>\text { We should give time for ourselves to take a rest }
\end{aligned}
$$

\section{Possessive Pronouns}

Possessive pronouns function as adjective that indicates ownership or relationship. It can be identified as first, second, or third person and singular or plural. It is also used to replace or to represent the possessive of the object, person or animal.

Singular : my, mine, your, yours, her, hers, his, its

Plural : our, ours, your, yours, their, theirs

\section{Examples :}

Singular $\quad \Rightarrow$ He is $\mathbf{m y}$ brother

Plural $\quad \Rightarrow$ It is our house

4. Relative Pronouns

Relative pronoun is used to combine two sentences that have the same noun or pronouns in them. Relative pronouns form the beginning of a relative clause. There are five basic of relative pronouns forms: that, who, which, whose, elliptical relative pronoun.

Example $\quad \Rightarrow$ That looks like our car

\section{RESEARCH METHOD}

In this research, the writer uses qualitative research because the data of the research is non-numerical but presented in words. Bogdan \& Biklen (2007: 5) state that qualitative research is a descriptive research, then data is presented in words or picture rather than numbers. Camara et al. (2007: 1) state that qualitative research is kind of research that primarily concerned understanding human beings' experiences in a humanistic and identifying diverse methodologies including focusing on analysis of text, and diverse forms of data collection along with criteria for evaluating qualitative research.

The research is qualitative research. It is called as a descriptive qualitative research. Denzin \& Lincoln (2005) as cited in Creswell (2007: 36) explain that qualitative analysis is a research that locates the observer within the world. It consists of asset of interpretive, material, practices that make the world visible. They turn the world into series representations, as well as field notes, interviews, conversations, images, recording and memos to the self. Qualitative analysis involves associate instructive, representational approach to the world, this implies that qualitative scientist study things in their natural, setting, trying to form sense or interpreter, phenomena in terms of meanings people bring to them.

\section{DATA ANALYSIS}

\section{The Data Analysis}

In this research, the data were taken from 30 students of SMAKatolik Cinta Kasih Tebing Tinggi. The writer asked the students of XI-MIA-1 to write one of the topics that has been selected of descriptive text such as (1) My favorite food, (2) My idol, (3) My family, (4) My best friend(s), (5) Covid 19. This research was conducted on $27^{\text {th }}$ and $28^{\text {th }}$ August 2020 by online. Because of the condition during 
the pandemic, the writer conducted the research by online. She used Whatsapp group and the students sent the picture of their result to the writer. The writer identified all occurrences of errors on the use pronoun made by the students and classified them by using Dulay's surface strategy taxomony, namely: omission, addition,misformation, misordering.

The formula of analyzing based of the types of errors is shown as follows :

$$
\mathrm{P}=\frac{F}{N} \mathrm{X} 100 \%
$$

Where: $\quad \mathrm{P}=$ Percentage of error

$\mathrm{F}=$ Frequency of error made

$\mathrm{N}=$ Number of students' error or the total number of error students made
1. The Error of subject pronoun
$=\frac{25}{88}$
$X 100 \%=28,4 \%$
2. The Error of object pronoun
$=\frac{29}{88}$
$\mathrm{X} 100 \%=33 \%$
3. The Error of possessive adjective $=\frac{34}{88}$
$\mathrm{X} 100 \%=38,6 \%$
4. The Error of possessive pronoun $=\frac{0}{88}$
$\mathrm{X} 100 \%=0 \%$
5. The Error of reflective pronoun
$=\frac{0}{88} \quad X 100 \%=0 \%$

Table 1.

The Frequency and percentage of Students' Errors

\begin{tabular}{|c|l|c|c|}
\hline No & \multicolumn{1}{|c|}{$\begin{array}{c}\text { Types of Error } \\
\text { Erequency of } \\
\text { Errors }\end{array}$} & $\begin{array}{c}\text { Percentage of } \\
\text { Error }\end{array}$ \\
\hline $\mathbf{1}$ & The Error of subject pronoun & $\mathbf{2 5}$ & $\mathbf{2 8 , 4} \%$ \\
\hline $\mathbf{3}$ & $\begin{array}{l}\text { The Error of object pronoun } \\
\text { adjective }\end{array}$ & $\mathbf{2 9}$ & $\mathbf{3 3} \%$ \\
\hline $\mathbf{4}$ & $\begin{array}{l}\text { The Error of possessive } \\
\text { pronoun }\end{array}$ & $\mathbf{3 4}$ & $\mathbf{3 8 , 6} \%$ \\
\hline $\mathbf{5}$ & $\begin{array}{l}\text { The Error of reflective } \\
\text { pronoun }\end{array}$ & $\mathbf{0}$ & $\mathbf{0} \%$ \\
\hline
\end{tabular}


Diagram 1. The percentage of Students' Errors based of types of error

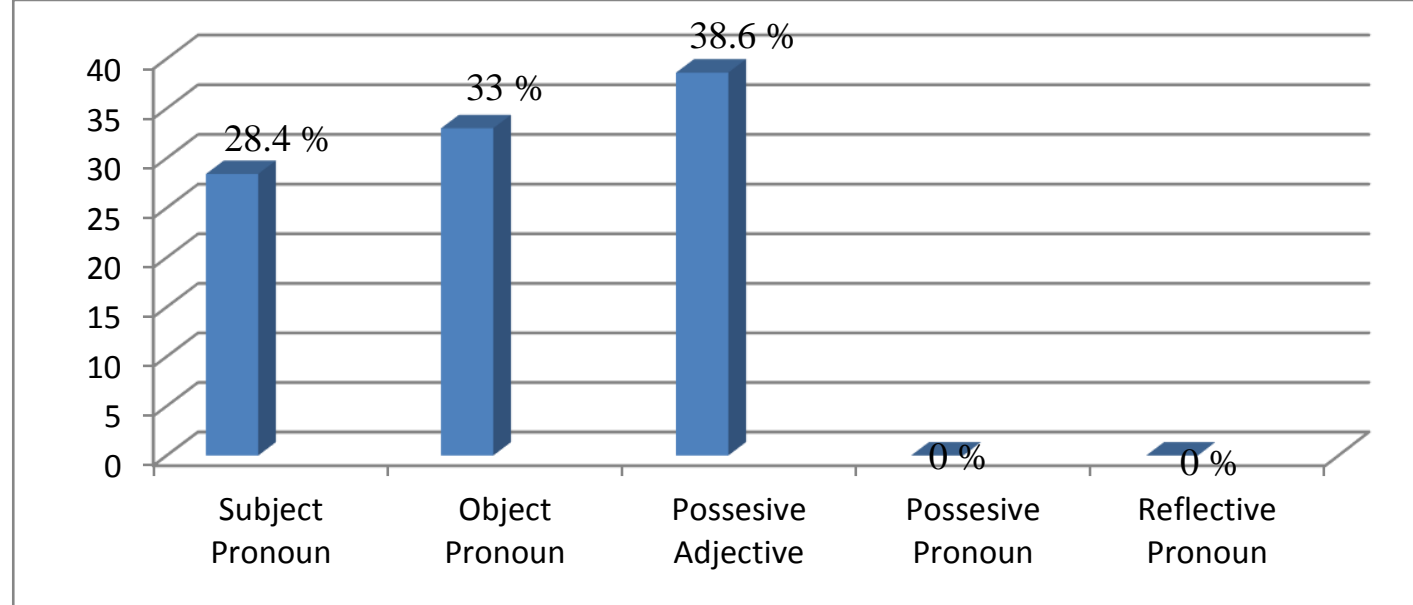

Based of the table above, it could seen that highest percentage is possessive adjective $38,6 \%$, followed by objective pronoun $33 \%$, subject pronoun $28,4 \%$, possessive pronoun $0 \%$, and reflective pronoun $0 \%$. follows :

The formula of analyzing based of the classification of errors is shown as

$$
\mathrm{P}=\frac{F}{N} \mathrm{X} 100 \%
$$

Where: $\quad \mathrm{P}=$ Percentage of error

$\mathrm{F}=$ Frequency of error made

$\mathrm{N}=$ Number of students' error or the total number of error students made
1. The Error of Omission
$=\frac{19}{169} \times 100 \%=11,2 \%$
2. The Error of Addition
$=\frac{60}{169} \times 100 \%=35,5 \%$
3. The Error of Misformation
$=\frac{88}{169} \times 100 \%=52,0 \%$
4. The Error of Misordering
$=\frac{2}{169} \times 100 \%=1,1 \%$

Table 2.

The Frequency and percentage of Students' Errors

\begin{tabular}{|c|l|c|c|}
\hline No & \multicolumn{1}{|c|}{$\begin{array}{c}\text { Types of Error } \\
\text { Frequency of } \\
\text { Errors }\end{array}$} & $\begin{array}{c}\text { Percentage of } \\
\text { Error }\end{array}$ \\
\hline $\mathbf{1}$ & The Error of Omission & $\mathbf{1 9}$ & $\mathbf{1 1 , 2} \%$ \\
\hline $\mathbf{3}$ & The Error of Addition & $\mathbf{6 0}$ & $\mathbf{3 5 , 5} \%$ \\
\hline $\mathbf{4}$ & The Error ofMisformation & $\mathbf{8 8}$ & $\mathbf{5 2 , 0} \%$ \\
\hline
\end{tabular}


Diagram 2. The percentage of Students' Errors based of classification of error

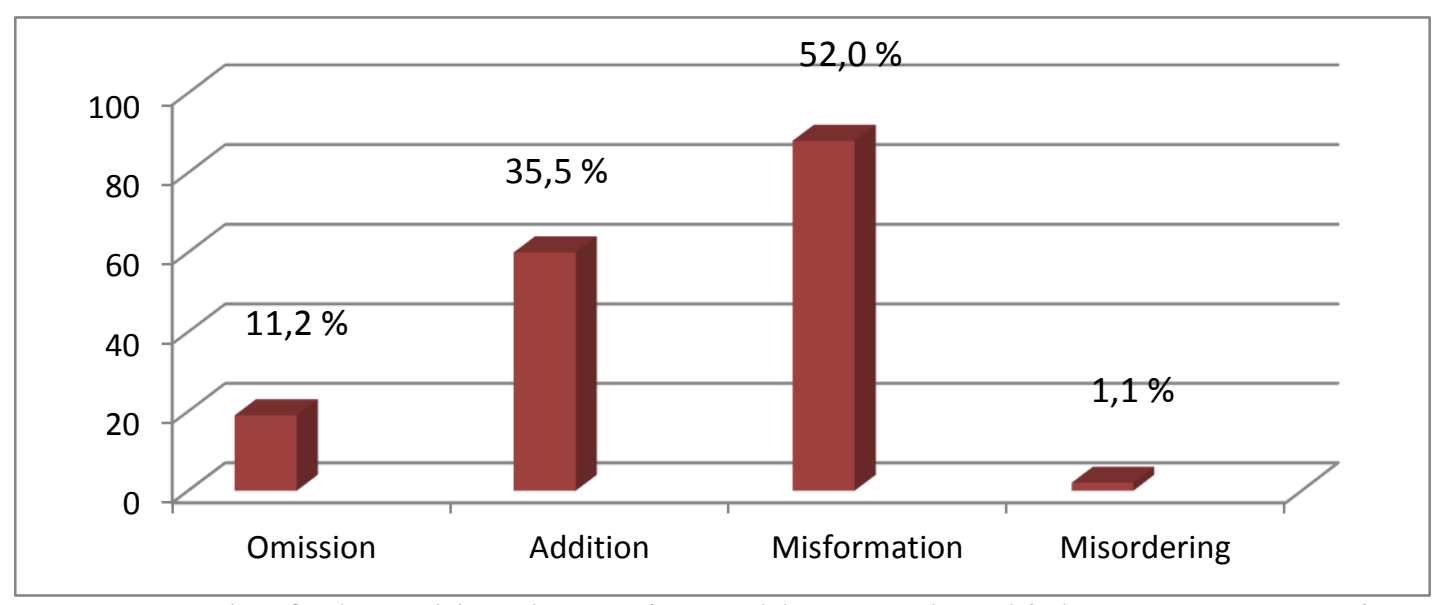

Based of the table above, it could seen that highest percentage is misformation $52,0 \%$, followed by addition $35,5 \%$, omission $11,2 \%$, and the last misordering 2 errors or $1,1 \%$.

\section{Interview}

The writer interviewed 10 students of 30 students to know the causes of error the writer did interview to students of XI-MIPA-1, and the writer was discussed with students by online. Interview was conducted by the writer in order to find out the reason of students in making the errors on using pronoun.

Based on the interview's result, from the question number 1, there were 6 of 10 students said that English subject is difficult, 3 of 10 students said that English subject is boring and 10 students said that English subject is important. From the question number 2, there were 10 students said that the teacher did not use media in the teaching learning process. From the question number 3, there were 10 students are happy if media or some interesting method used in the teaching learning process by teacher. From the question number 4, there were 5 of 10 students said that they were still confused about the functions of pronoun and there were 5 of 10 students said that they do not understand when the teacher explained the material. In the last question or number 5, there were 10 students said that they the teacher should use media in the teaching learning process and create some interesting teaching, so that it can increase the students' interest in learning English. The interview sheet can be seen in appendix.

\section{CONCLUSIONS}

Based on the data described in the previous chapter, the writer drew some conclusions as follow :

1. Based on the types of errors, the dominant errors made by the students : the first possessive adjective was 34 errors or $38,6 \%$. The second, object pronoun was 29 errors or $33 \%$. The third, subject pronoun was 25 errors or $28,4 \%$. There were no errors made by the students in possessive pronoun and reflective pronoun $0 \%$.

2. Based on the classification of errors, the dominant errors made by the students : the first Misformation was 88 errors or $52,0 \%$. The second, addition was 60 errors or $35,5 \%$. The third, omission was 19 errors or $11,2 \%$. The last misordering was 2 errors or $1,1 \%$. 
3. The causes of errors were caused of their less motivation of learning, lack of knowledge about grammar and English language, and minimal use of media by the teacher during teaching learning process. The teacher should create an interesting teaching, so it that can increase the students' interest in learning English. The students were expected to learn more consistently to comprehend pronouns.

\section{BIBLIOGRAPHY}

Bodgan \& Biklen. 2007. Qualitative Research for Education: an Introduction to Theory and Methods 5th edition. Boston: Pearson Education Inc.

Brown, H. D. 2007. Principles of Language and Teaching. New York: Pearson Education.

Camara et al. 2007. Qualitative Research Reports in Communication. London: Routledge.

Denzin, N. and Lincoln, Y. 2005. Introduction: discipline and practice of qualitative research. Thousand Oaks: California.

Dulay, H. 1982. Language Two. Oxford: Oxford University Press.

Harmer, J. 2001. How to Teach English. England: Pearson Education Limited.

James, C. 2001. Error in Language Use: exploring Error Analysis. Beijing: Foreign Language Teaching and Research Press.

Kumar, K. 2019. Parts of Speech (Pronoun). Chaman: KK Publications.

Meyers, A. 2005. Gateways to Academic Writing: Effective Sentences Paragraph and Essay. New York: Longman.

Minichiello, V. 2009. In-depth Interviewing: Researching People. Melbourne: Longman Cheshire

Murphy, R. 1998. English Grammar in Use. New York: Cambridge University Press.

Norrish, J. 1983. Language Learner and Their Error. London: Mac Millan Publisher, Ltd.

Payne, T. E. 2011. Understanding English Grammar: A Linguistic Introduction. New York: Cambridge University Press.

Spillner, B. 2017. Error Analysis in the World. New York: Pearson Education. 
Suryani and Hidayatullah. 2017. Error Analysis of The Students' Test Result on Using Personal Pronouns. Dedikasi Pendidikan Journal, 1 (1), 65-73.

Susanti, D. 2018. An Error Analysis on Pronouns Used by The Eight-Grade Students at SMPN 18 Malang in Writing Recount Texts. An Unpublished Sarjana's Thesis, Faculty of English Language Education Department Teacher Training And Education: University of Muhammadiyah Malang.

Sutor, M. 2015. Non-native Speech in English Literature. Munchen: Herbert Utz Verlag GmbH. 